\title{
Modulatory Effect of Ascorbic Acid on Propofol-Induced Anaesthesia in Goats
}

\author{
Veronica Inyamu Ochigbo ${ }^{1,}$, Joseph Olusegun Ayo², Tagang Aluwong ${ }^{2}$ \\ ${ }^{1}$ Department of Physiology, Pharmacology and Biochemistry, University of Agriculture, Makurdi, Nigeria \\ ${ }^{2}$ Department of Veterinary Physiology, Ahmadu Bello University, Zaria, Nigeria
}

Email address:

veronicaochigbo@gmail.com (V. I. Ochigbo), ayojo94@yahoo.com (J. O. Ayo), tagang@yahoo.co.uk (T. Aluwong)

*Corresponding author

\section{To cite this article:}

Veronica Inyamu Ochigbo, Joseph Olusegun Ayo, Tagang Aluwong. Modulatory Effect of Ascorbic Acid on Propofol-Induced Anaesthesia in Goats. Journal of Anesthesiology. Vol. 5, No. 3, 2017, pp. 19-23. doi: 10.11648/j.ja.20170503.11

Received: May 15, 2017; Accepted: May 25, 2017; Published: July 17, 2017

\begin{abstract}
Ascorbic acid modulates the central nervous system either physiologically or pharmacologically, and has been proposed to function as a neuromodulator. The effect of ascorbic acid (AA, vitamin C) on some physiological parameters, onset and duration of anaesthesia following propofol anaesthesia was evaluated in goats. A total of 24 goats divided into four groups, comprising five goats each in groups I and II, and seven goats each in groups III and IV were used for the experiment. Groups I and II served as control for AA $(200 \mathrm{mg} / \mathrm{kg})$ and propofol $(5 \mathrm{mg} / \mathrm{kg})$ intravenous treatments, respectively; while groups III and IV received AA at $200 \mathrm{mg} / \mathrm{kg}$ and $300 \mathrm{mg} / \mathrm{kg}$, respectively before propofol anaesthesia. The result showed that AA significantly $(\mathrm{P}<0.05)$ decreased the onset of anaesthesia and increased the duration of propofol anaesthesia in goats. AA $(300 \mathrm{mg} / \mathrm{kg})$ induced a decrease $(\mathrm{P}<0.05)$ in respiratory rate during anaesthesia, but there were no significant changes in heart rate and rectal temperature in the groups. In conclusion, AA potentiated the effect of propofol - induced anaesthesia in goats without alteration in heart rate and rectal temperature.
\end{abstract}

Keywords: Propofol, Ascorbic Acid, Goat, Physiological Parameters, General Anaesthesia

\section{Introduction}

Anaesthesia is seldom accomplished by a single drug because no single drug is able to provide all components of anaesthesia without seriously compromising haemodynamic and/or respiratory function, reducing operating conditions or delaying postoperative recovery [1]. Propofol is a popular intravenous (IV) anaesthetic drug, used for induction and maintenance of general anaesthesia owing to its rapid onset and short duration [2]. The rapid onset, short duration of action and with rapid recoveries makes propofol useful in ruminants, in which these features are particularly desirable [3]. Reports on the use of propofol for induction and maintenance of anaesthesia have indicated its suitability in goats [4-6] and even sheep [7]; where it was used at $4 \mathrm{mg} / \mathrm{kg}$, but with halothane as maintenance and acepromazine as premedication in goats and sheep, respectively. Propofol contains a phenolic O-H group [8], and many polyphenols have antioxidant properties [9]. It has been reported that propofol may replace $\alpha$-tocopherol (vitamin E) as an antioxidant [8] as it chemically resembles $\alpha$ - tocopherol which also has a phenolic hydroxyl group. It was shown that introducing propofol into $\alpha$-tocopherol-depleted microsomes, restores the GSH-dependent protection. Thus, propofol is a potent inhibitor of lipid peroxidation [10].

Ascorbic acid (AA) is a water-soluble micronutrient required for multiple biological functions [11]. All known physiological and biochemical actions of AA are due to its action as an electron donor or a reducing agent $[12,13]$. AA acts as a potent water-soluble antioxidant in biological fluids by scavenging physiologically relevant reactive oxygen species and reactive nitrogen species [14]. Reports on the influence of AA on xylazine anaesthesia [15] and ketamine anaesthesia in rabbits [16] showed that the vitamin potentiates anaesthesia. Ketamine-xylazine combination in rats has also been demonstrated to improve anaesthesia in this species, when given in combination with AA [17]. AA modulates the central nervous system either physiologically or pharmacologically, and high amount exerts similar 
physiological effects as amphetamine in the central nervous system [16]. Ascorbate has been proposed to function as a neuromodulator of both dopamine and glutamate-mediated neurotransmission [18, 19]. Its plasma concentrations are tightly controlled when the vitamin is taken orally, even at the highest tolerated amounts [20]. By contrast, intravenous administration bypasses tight control and results in concentrations as much as 70-fold higher than those achieved by maximum oral consumption. Most of the positive effects of ascorbate follow its parenteral administration because much higher effective doses can be given by this route compared to oral administration [21]. The role of AA in modulating general anaesthesia is not completely understood. It has been suggested that the vitamin plays a role in diethyl ether-induced anaesthesia [17]. Since then, very few works have been done and no real attempts have been made to investigate its interaction with the modern anaesthetic agents. Although, the effects of stress and anaesthesia may predispose the animal to cardio-respiratory arrests, the administration of AA may reduce the cost and dose of anaesthetics required for general anaesthesia and minimise the risk to the patient's health [15].

The aim of this study was to determine the role of AA in modulating propofol anaesthesia in goats.

\section{Materials and Methods}

\subsection{Experimental Animals}

Twenty four, apparently, healthy Red Sokoto goats aged 12 years and weighing between $12-20 \mathrm{~kg}$ were used in the study. The animals were randomly divided into four experimental groups (I - IV). They were housed in a goat pen at the Department of Physiology, Faculty of Veterinary Medicine, Ahmadu Bello University, Zaria, Nigeria. The goats were pre-conditioned for a period of four weeks before the commencement of the experiment, during which prophylactic treatment was carried out with anthelmintic using albendazole orally at a dose rate of $7.5 \mathrm{mg} / \mathrm{kg}$, and the topical ectoparasiticide, cypermetrin administered to the goats at the dose rate of $1 \mathrm{ml} / \mathrm{kg}$. The goats were given access to hay, groundnut hops, beans stalk and water ad libitum throughout the study period, except during the induction of anaesthesia. The procedures used in the present study follow the guiding principle for the care and use of animals in research [22] and declaration of Helsinki.

\subsection{Experimental Design}

Before induction of anaesthesia, feed and water were withdrawn from the animals for 24 hours and 12 hours, respectively. Baseline rectal temperature, respiratory rate and heart rate were taken in all the groups before the commencement of induction. Group I animals were given AA (Philo VC; Greenfield Pharmaceutical Jiang Su, China) intravenously at a dose rate of $200 \mathrm{mg} / \mathrm{kg}$. The intravenous administration of drugs was done using the jugular vein with 21 gauge needles. Group II animals were administered with propofol (Dipirivan; AstraZeneca, Place Renault, Milano, Italy. $1 \%$ Emulsion) intravenously at a dose rate of $5 \mathrm{mg} / \mathrm{kg}$, group III was given a combination of propofol $(5 \mathrm{mg} / \mathrm{kg})$ and $\mathrm{AA}$, at a dose rate of $200 \mathrm{mg} / \mathrm{kg}$; and group IV was administered with AA at a dose rate of $300 \mathrm{mg} / \mathrm{kg}$ and propofol $(5 \mathrm{mg} / \mathrm{kg})$. AA was administered 30 seconds before propofol injection. The time of administration of the agent was recorded. The physiological parameters were recorded for each group before, during and after the treatment. The onset and duration of anaesthesia in each group were observed and recorded. Onset of anaesthesia was evident by the loss of external stimuli. The respiratory rate, heart rate and the rectal temperature were measured using standard methods [23]. The readings were taken before induction of anaesthesia, and continued throughout the induction period for every 5 minutes until full recovery was attained.

\subsection{Statistical Analysis}

Values obtained are expressed as mean \pm SEM. Data were analyzed using one-way analysis of variance with Tukey's multiple comparison post-hoc test using GraphPad prism version 4.0 (from GraphPad Software, San Diego, California, U.S.A.). Values of $\mathrm{P}<0.05$ were considered significant.

\section{Results}

\subsection{Effect of Ascorbic Acid Administration on Onset and Duration of Anaesthesia}

There was a significant decrease in the onset of anaesthesia of goats in group IV when compared to that of group II or group III goats (Table 1). Goats that received AA alone were not anaesthetised while administration of 200 $\mathrm{mg} / \mathrm{kg}$ and $300 \mathrm{mg} / \mathrm{kg}$ AA before propofol injection induced anaesthesia; with the onset time of $2.57 \pm 0.30$ seconds and $2.00 \pm 0.22$ seconds, respectively. The duration of propofol anaesthesia was significantly higher in animals of group IV compared to that of group II or group III animals.

The duration of anaesthesia after treatment with propofol alone was $10.60 \pm 4.42$ minutes. The administration of 200 $\mathrm{mg} / \mathrm{kg}$ and $300 \mathrm{mg} / \mathrm{kg}$ AA prior to propofol injection induced anaesthesia with a longer duration significantly different from that of animals on anaesthetic agent alone (Table 1).

Table 1. Effect of ascorbic acid and Propofol on onset and duration of anaesthesia in goats (Mean \pm SEM).

\begin{tabular}{llll}
\hline Groups & n & $\begin{array}{l}\text { Onset of anaesthesia } \\
\text { (Seconds) }\end{array}$ & $\begin{array}{l}\text { Duration of anaesthesia } \\
\text { (Minutes) }\end{array}$ \\
\hline Group I & 5 & Not applicable & Not applicable \\
Group II & 5 & $4.60 \pm 0.68^{a}$ & $10.60 \pm 4.42^{a}$ \\
Group III & 7 & $2.57 \pm 0.30^{b}$ & $15.29 \pm 1.19^{a}$ \\
Group IV & 7 & $2.00 \pm 0.22^{b}$ & $27.29 \pm 4.11^{b}$ \\
\hline
\end{tabular}

Group I = Ascorbic acid (200 mg/kg); Group II = Propofol (5 mg/kg); Group $\mathrm{III}=$ Ascorbic acid at $200 \mathrm{mg} / \mathrm{kg}$ and Propofol at $5 \mathrm{mg} / \mathrm{kg}$; Group IV = Ascorbic acid at $300 \mathrm{mg} / \mathrm{kg}$ and Propofol at $5 \mathrm{mg} / \mathrm{kg}$.

$a, b=$ Means with different superscript letters are statistically significant $(\mathrm{P}<$ $0.05)$. 


\subsection{Effect of Ascorbic Acid Administration on Physiological Parameters with Propofol Anaesthesia}

There were no significant changes in heart rate of goats following administration of AA alone. Administration of propofol alone did not significantly alter the heart rate of goats during anaesthesia; neither did the administration of both AA and propofol (Table 2).

Table 2. Mean heart rate (beats/min) observed following intravenous administration of ascorbic acid and Propofol in goats (Mean \pm SEM).

\begin{tabular}{lllll}
\hline Groups & $\mathbf{n}$ & $\begin{array}{l}\text { Before } \\
\text { induction }\end{array}$ & During induction & $\begin{array}{l}\text { After } \\
\text { induction }\end{array}$ \\
\hline Group I & 5 & $104.2 \pm 22.7$ & Not applicable & $81.2 \pm 8.1$ \\
Group II & 5 & $108.0 \pm 12.5$ & $106.0 \pm 12.8$ & $123.2 \pm 9.3$ \\
Group III & 7 & $84.0 \pm 10.8$ & $96.3 \pm 9.4$ & $105.7 \pm 10.4$ \\
Group IV & 7 & $93.1 \pm 13.7$ & $112.6 \pm 9.5$ & $108.0 \pm 10.1$ \\
\hline
\end{tabular}

Group I = Ascorbic acid (200 mg/kg); Group II = Propofol (5 mg/kg); Group III = Ascorbic acid at $200 \mathrm{mg} / \mathrm{kg}$ and Propofol at $5 \mathrm{mg} / \mathrm{kg}$; Group IV = Ascorbic acid at $300 \mathrm{mg} / \mathrm{kg}$ and Propofol at $5 \mathrm{mg} / \mathrm{kg}$.

As shown in the Table 3, the administration of AA alone did not cause significant changes in the respiratory rate of the goats. Propofol when given alone did not change the respiratory rate of goats significantly during and after anaesthetic induction. There was also no significant change in respiratory rate when $200 \mathrm{mg} / \mathrm{kg}$ AA was given to the goats prior to propofol induction. However, a significant decrease in respiratory rate occurred following administration of $300 \mathrm{mg} / \mathrm{kg}$ AA before propofol administration, although the value rose after anaesthesia from $21.1 \pm 1.7$ breaths $/ \mathrm{min}$ to $25.1 \pm 0.7$ breaths $/$ min (Table 3 ).

Table 3. Mean respiratory rate (breaths/min) observed following intravenous administration of ascorbic acid and Propofol in goats (Mean \pm SEM).

\begin{tabular}{lllll}
\hline Groups & $\mathbf{n}$ & $\begin{array}{l}\text { Before } \\
\text { induction }\end{array}$ & $\begin{array}{l}\text { During } \\
\text { induction }\end{array}$ & $\begin{array}{l}\text { After } \\
\text { induction }\end{array}$ \\
\hline Group I & 5 & $26.4 \pm 5.60$ & Not applicable & $27.2 \pm 2.90$ \\
Group II & 5 & $28.0 \pm 4.00$ & $22.0 \pm 6.10$ & $18.4 \pm 2.00$ \\
Group III & 7 & $31.4 \pm 3.00$ & $23.4 \pm 3.80$ & $22.9 \pm 3.10$ \\
Group IV & 7 & $33.3 \pm 2.10^{a}$ & $21.1 \pm 1.70^{b}$ & $25.1 \pm 0.70^{b}$ \\
\hline
\end{tabular}

Group I = Ascorbic acid (200 mg/kg); Group II = Propofol (5 mg/kg); Group III = Ascorbic acid at $200 \mathrm{mg} / \mathrm{kg}$ and Propofol at $5 \mathrm{mg} / \mathrm{kg}$; Group IV = Ascorbic acid at $300 \mathrm{mg} / \mathrm{kg}$ and Propofol at $5 \mathrm{mg} / \mathrm{kg}$.

$a, b=$ Means with different superscript letters are statistically significant $(\mathrm{P}<$ $0.05)$.

Table 4. Mean rectal temperature $\left({ }^{\circ} \mathrm{C}\right)$ values observed following intravenous administration of ascorbic acid and Propofol in goats (Mean \pm SEM).

\begin{tabular}{lllll}
\hline Groups & $\mathbf{n}$ & $\begin{array}{l}\text { Before } \\
\text { induction }\end{array}$ & $\begin{array}{l}\text { During } \\
\text { induction }\end{array}$ & $\begin{array}{l}\text { After } \\
\text { induction }\end{array}$ \\
\hline Group I & 5 & $37.9 \pm 0.18$ & Not applicable & $38.2 \pm 0.32$ \\
Group II & 5 & $37.9 \pm 0.25$ & $38.3 \pm 0.46$ & $38.1 \pm 0.40$ \\
Group III & 7 & $37.9 \pm 0.21$ & $38.2 \pm 0.30$ & $38.0 \pm 0.30$ \\
Group IV & 7 & $38.5 \pm 0.30$ & $38.7 \pm 0.30$ & $38.3 \pm 0.70$ \\
\hline
\end{tabular}

Group I = Ascorbic acid (200 mg/kg); Group II = Propofol ( $5 \mathrm{mg} / \mathrm{kg})$; Group III = Ascorbic acid at $200 \mathrm{mg} / \mathrm{kg}$ and Propofol at $5 \mathrm{mg} / \mathrm{kg}$; Group IV = Ascorbic acid at $300 \mathrm{mg} / \mathrm{kg}$ and Propofol at $5 \mathrm{mg} / \mathrm{kg}$.

The administration of AA alone did not alter $(\mathrm{P}>0.05)$ the rectal temperature in the goats significantly. Propofol when given alone did not cause significant changes in the rectal temperature during or after anaesthesia of the goats. Administration of AA at both doses before propofol anaesthesia also did not significantly alter the rectal temperature of the goats (Table 4).

\section{Discussion}

The results obtained from the experiment showed that AA pre-treatment before propofol administration affected the onset and duration of sleep following propofol anaesthesia in goats. The decrease in onset and increase in the duration of anaesthesia obtained in the present study was dose-dependent and further showed that, the changes were insignificant at a low dose. The fact that changes became significant at a higher dose demonstrated that AA may act by exerting inhibitory effects on the central nervous system, inducing depression. This finding is in agreement with the result obtained by Elsa and Ubandawaki [16], which showed that AA when administered at high doses prolonged the duration of ketamine-induced anaesthesia in rabbits. Propofol causes central nervous system depression by enhancing or potentiating the actions of $\mathrm{GABA}$ at the $\mathrm{GABA}_{\mathrm{A}}$ receptors $[24,25]$ and $A A$ has also been reported to potentiate GABAergic neurotransmission in the central nervous system [26]. The combined effect of both propofol and AA on $\mathrm{GABA}_{\mathrm{A}}$ receptors may lead to the increase in duration and decrease in the onset of anaesthesia. Furthermore, the result shows that administration of AA alone decreased heart rate in goats. This finding disagreed with that of [15], who reported an increase in heart rate after administration of AA (120 $\mathrm{mg} / \mathrm{kg}$ ) alone to rabbits. The difference in the results may be due to species difference and the use of a higher dose (200 $\mathrm{mg} / \mathrm{kg}$ ) of AA in this study. The observed decrease may be caused by the depressant activity of AA in the central nervous system [16]. Propofol when administered alone was shown to cause an initial decrease in heart rate. This finding showed that propofol depressed the central nervous system directly, as do most other intravenous anaesthetic induction agents. Thus, heart rate apparently decreased by direct depressant action of propofol on the sinus node [27]. However, propofol administration was shown to cause an increase in heart rate after induction which is in agreement with the finding of Robinson et al, [28] and Shah et al, [29], who reported increases in heart rate after propofol administration. Kanaya et al, [30] have shown no significant changes in heart rate, but Mcintosh et al, [27] reported an initial increase in heart rate during propofol anaesthesia, followed by a decrease in rabbits. In the present study, the administration of AA before propofol administration caused no significant changes in heart rate and rectal temperature.

Ascorbic acid when administered alone did not alter the respiratory rate of the animals. This finding disagrees with that of Egwu et al, [15], who reported a decrease in respiratory rate after AA administration in rabbits. The result of the present study showed that propofol when administered 
alone decreased the respiratory rate only after induction, which agreed with the result obtained by De Cosmo et al, [31] that propofol possesses profound respiratory depressant properties in humans. Goats administered with $300 \mathrm{mg} / \mathrm{kg}$ AA before propofol induction showed a decrease in respiratory rate during induction. Since AA induces central nervous system depressant activity at large doses, the combined depressant effect of propofol and large doses of AA may be responsible for the significant respiratory depression recorded in the present study. However after induction, there was an increase in respiratory rate in goats administered with $300 \mathrm{mg} / \mathrm{kg}$ AA. This finding may be due to the fact that the group experienced a longer duration of anaesthesia. The respiratory depressant effect of propofol resolves quickly once the drug is cleared from the blood, and propofol rapidly clears from the blood [32]. The prolongation of the duration of anaesthesia may be of value in reducing the amount of propofol used, especially when given during a lengthy surgical procedure, or when propofol is needed as a maintenance anaesthetic. This may also prevent the occurrence of respiratory depression caused by propofol anaesthesia. It is, therefore, recommended that AA be pre-medicated before propofol anaesthesia in goats for surgical intervention requiring long duration.

\section{Conclusion}

AA potentiates the effect of propofol by prolonging the duration of anaesthesia, when administered in goats. This is important as it can prevent the use of a maintenance dose with propofol or other anaesthetic agents during prolonged procedure in this specie of animal, thereby reducing anaesthetic cost. Administration of propofol after premedication with ascorbic acid is safe and exerts low adverse effect on physiological parameters such as heart rate, respiratory rate and rectal temperature.

\section{References}

[1] J. Vuyk, Pharmacokinetic and pharmacodynamic interactions between opioids and propofol, J Clin Anaesth, vol. 9, pp. 23, 1997.

[2] H. Kang, M. Kwon, B. Choi, M. Koo, Y. Jang, M. Lee, Clinical factors affecting the pain on injection of propofol, Korean J. Anaesthesiol, vol. 58 (3), pp. 239-243, 2010.

[3] N. N. Prassinos, A. D. Galatos, D. Raptopoulos, A comparison of propofol, thiopental or ketamine as induction agents in goats, Vet Anaesth Analg, vol. 32 (5), pp. 289-296, 2005.

[4] A. M. Nolan, J. Reid, E. Welsh, The use of propofol as an induction agent in goats, Vet Anaesth Analg, vol. 18, pp. 5354, 1991 (abstract).

[5] J. Reid, A. M. Nolan, E. Weish, Propofol as an induction agent in the goat - a pharmacokinetic study, J Vet Pharmacol Ther, vol. 16, pp. 488-493, 1993.

[6] L. S. Pablo, J. E. Bailey, J. C. H. Ko, Median effective dose of propofol required for induction of anaesthesia in goats, $\mathrm{J}$ Am Vet Med Assoc, vol. 211, pp. 86-88, 1997.
[7] D. Correia, A. M. Nolan, J. Reid, Pharmacokinetics of propofol infusions, either alone or with ketamine, in sheep premedicated with acepromazine and papaveretum, Res Vet Sci, vol. 60, pp. 213-217, 1996.

[8] L. Aarts, R. Van der hee, I. Dekker, J. Jong, H. Langegemeijer, A. Bast, The widely used anaesthetic agent propofol can replace alpha-tocopherol as an antioxidant, FEBS Letters, vol. 357, pp. 83-85, 1995.

[9] G. L. Volti, P. Murabito, G. Attaguile, L. F. Rodella, M. Astuto, C. D. Giacomo, A. Gullo, Antioxidant properties of propofol: When oxidative stress sleeps with patients, EXCLI, vol. 5, pp. 25-32, 2006.

[10] P. G. Murphy, D. S. Myers, M. J. Davies, N. R. Webster, J. G. Jones, The antioxidant potential of propofol, Br J Anaesth, vol. 68 , pp. 613- 618, 1992.

[11] L. T. Duarte, J. Lunec, When is an antioxidant not an antioxidant? A review of novel actions and reactions of vitamin C, Free Radic Res, vol. 39 (7), pp. 671-686, 2005.

[12] N. Sarkar, P. K. Srivastava, V. K. Dubey, Understanding the Language of vitamin C, Curr Nutr Food Sci, vol. 5, pp. 53-55, 2009.

[13] A. K. Schlueter \& C. S. Johnston, Vitamin C: Overview and Update, J Evid Based Complementary Altern Med, vol. 16(1), pp. 49-57, 2011.

[14] B. Halliwell, Free radicals, proteins and DNA: oxidative damage versus redox regulation, Biochem Soc Trans, vol. 24, pp. 1023-1027, 1996.

[15] G. O. Egwu, G. D. Mshelia, S. Sanni, P. A. Onyeyili, G. T. Adeyanju, The effect of vitamin $\mathrm{C}$ at varying times on physiological parameters in rabbits after xylazine anaesthesia, Vet Ital, vol. 47 (1), pp. 97-104, 2011.

[16] A. Elsa, S. Ubandawaki, Ketamine anaesthesia following premedication of rabbits with vitamin C, J Vet Sci, vol. 6 (3), pp. 239-241, 2005.

[17] A Najafpour, G. Sadeghi-hashjin, Vitamin C pre-medication enhances the anaesthetic effect of ketamine-xylazine combination in the rat, Arch Med Sci, vol. 3 (4), pp. 340-343, 2007.

[18] R. A. Grunewald, Ascorbic acid in the brain. Brain Res Rev, vol. 18, pp. 123-133, 1993.

[19] G. V. Rebec, R. C. Pierce, A vitamin as neuromodulator: ascorbate release into the extracellular fluid of the brain regulates dopaminergic and glutamatergic transmission, Prog Neurobiol, vol. 43, pp. 537-565, 1994.

[20] S. J. Padayatty, H. Sun, Y. Wang, H. D. Riordan, S. M. Hewitt, A. Katz, R. A. Wesley, M. Levine, Vitamin C pharmacokinetics: implications for oral and intravenous use, Ann Intern Med, vol. 140, pp. 533-537, 2004.

[21] F. E. Harrison, M. May, Vitamin C function in the brain: Vital role of the ascorbate transporter SVCT2, Free Radic Biol Med, vol. 46, pp. 719-730, 2009.

[22] World Medical Association; American Physiological Society, Guiding principles for research involving animals and human beings. Am J Physiol Regul Integr Comp Physiol, vol. 283 (2), R281-3, 2002. 
[23] M. A. H. Ghurashi, H. I. Seri, A. H. Bakheit, E. A. M. Ashwag, J. A. Abakar, Evaluation of ketamine/diazepam anaesthesia for performing surgery in desert goats under field condition, Aust J Basic \& Appl Sci, vol. 3 (2), 455-459, 2009.

[24] T. G. Hales, J. J. Lambert, The actions of propofol on inhibitory amino acid receptors of bovine adrenomedullary chromaffin cells and rodent central neurones, Bri J Pharmacol, vol. 104, pp. 621-628, 1992.

[25] M. Irifune, T. Tohru, S. Yoshitaka, E. Chie, K. Sohtaro, D. Toshihiro, K. Michio, Propofol-induced anaesthesia in mice is mediated by $\gamma$-aminobutyric acid-A and excitatory amino acid receptors, Anaesth Analg, vol. 97, pp. 424-429, 2003.

[26] C. I. Calero, E. Vickers, G. M. Cid, G. L. Aguayo, H. Gersdorff, D. J. Calvo, Allosteric modulation of retinal GABA receptors by ascorbic acid, J Neurosci, vol. 31 (26), pp. 9672$9682,2011$.

[27] M. P. Mcintosh, K. Iwasawa, R. A. Rajewski, T. Fujisawa, H. Goto, Haemodynamic profile in rabbits of fospropofol disodium injection relative to propofol emulsion following rapid bolus injection, J Pharm Sci, 2012. DOI $10.1002 /$ jps. 23162 .

[28] B. J. Robinson, H. C. Buyck, D. C. Galletly, Effect of propofol on heart rate, arterial pressure and digital plethysmograph variability, Bri J Anaesth, vol. 73 (2), pp. 173-176, 1994.

[29] N. K. Shah, M. Harris, K. Govindugari, H. B. Rangaswamy, $\mathrm{H}$. Jeon, Effect of propofol titration $\mathrm{v} / \mathrm{s}$ bolus during induction of anaesthesia on haemodynamics and bispectral index, Middle East J Anaesthesiol, vol. 21 (2), pp. 275-284, 2011.

[30] N. Kanaya, H. Naoyuki, K. Saori, N. Masayasu, N. Akiyoshi, Differential effects of propofol and sevoflurane on heart rate variability, Anaesthesiology, vol. 98 (1), pp. 34-40, 2003.

[31] G. De cosmo, E. Congedo, A. Clemente, P. Aceto, Sedation in the PACU: The role of propofol, Curr Drug Targets, vol. 6, pp. 741-744, 2005.

[32] J. Barr, Propofol: a new drug for sedation in the intensive care unit, Int Anaesthesiol Clin, vol. 33 (1), pp. 131-154, 1995. 